\title{
DELEUZE'S “CRYSTALS OF TIME”, HUMAN SUBJECTIVITY AND SOCIAL HISTORY
}

\section{Bert Olivier}

Senior Research Fellow in Philosophy

University of the Free State

OlivierG1@ufs.ac.za

\section{ABSTRACT}

This paper takes Deleuze's concept of the "crystals of time" - which condenses, metaphorically, different possibilities of what he calls the "time-image" in cinema - as its point of departure, and does in reverse what lan Buchanan does where he proposes that one can use the notion of "schizoanalysis" from Deleuze and Guattari's Anti-Oedipus for the exploration of cinema. In other words, what I do here is to transfer the notion of different time-crystals in cinema to different domains, namely those of human subjectivity and social history. The reason behind this attempt at cross-fertilisation is that, if one reads Deleuze's book on Kant together with that on the time-image in cinema, the parallel between Kant's revolutionary reconceptualisation of time (against the backdrop of the Aristotelian conception) and Deleuze's on the time-image in cinema (as opposed to the "movement-image") becomes apparent. It follows that, if time comprises the condition of the possibility of human subjectivity (for Kant), and the cinema of the time-image demonstrates that something similar holds for the "fullest" possibility of cinema - time here usurping the position held previously by movement in film - then the concepts employed by Deleuze to come to grips with the multiplicity of cinematic possibilities or virtualities and their actualisations may prove useful for articulating a model of human subjectivity and, at the level of collective subjectivities, social history. Deleuze's metaphor of "time-crystals" is therefore employed here, not only to give a brief outline of human subjectivity as temporally constituted, but further to focus on social history, or more specifically on different temporal/historical aspects, virtual and actual, of neoliberal capitalism. This is done via the four types of time-crystals distinguished by Deleuze (in cinema), namely the "perfect crystal", "flawed crystal", "crystal of seeds" and "decaying crystal".

\section{UNISA}


Keywords: Deleuze; crystals of time; time image; capitalism; cinema; reconceptualisation of subjectivity; virtuality

In his Introduction to The schizoanalysis of cinema (2008: location 63-89), Ian Buchanan argues that, "...in order to engage with cinema as a whole we need to take Deleuze as a whole", despite the fact that Gilles Deleuze himself deliberately excluded certain questions (that, in his view, did not elucidate the cinematic image as such) from the field of philosophical reflection on cinema. Buchanan does so in the interest of approaching their work with the same kind of creativity as that espoused by Deleuze and Guattari. He regards Deleuze's exclusion of seemingly extraneous questions as the "price he has to pay" for the precision with which he characterised the functioning of the film-image. Deleuze's strict focus has left it up to other film theorists, like Buchanan and his fellow-contributors to the volume in question, to fill the gap, as it were; hence the creative transfer of the concept of "schizoanalysis" from Deleuze and Guattari's work in Anti-Oedipus (1983), to an ostensibly heterogeneous field, namely that of cinema, with eye-opening results.

Taking my cue from Buchanan, I would like to reverse this process by using a concept employed by Deleuze in his work on the cinema of the time-image (2005), namely "time-crystals" to engage with questions concerning human subjectivity and social history. Reading Deleuze's book on Immanuel Kant (1999) together with that on the time-image in cinema (2005), the parallel, in one important respect, between Kant's revolutionary reconceptualisation of time and Deleuze's on the time-image in cinema becomes apparent, the other differences between their conceptions of time notwithstanding. This is because Kant's notion of time as the fundamental form structuring "rational" human experience, including that of movement, contrasts with the ancient (Aristotelian) conception, where time is regarded as the "measure of motion"(Deleuze 1999: vii-viii; 2005: xi). Analogously, Deleuze(2005: xi-xiii) claims that the cinema of the "time-image" upends the cinema of the "movement-image" by demonstrating that it is not motion, but time, that comprises the ground of varieties of cinematic experience, including that of motion. If one accepts Kant's claim that time comprises the condition of the possibility of human subjectivity, and the cinema of the time-image demonstrates that something similar holds for the cinema of the time-image (where time usurps the position held previously by movement in film) then it would appear that the concepts created by Deleuze to discern the multiplicity of cinematic possibilities or virtualities and their actualisations may prove suitable for articulating a complex model of human subjectivity and, at the level of collective subjectivities, social history. That is, if time is fundamental to human subjectivity, as well as to contemporary cinema, then the range of concepts articulated by Deleuze to grasp different nuances of time in cinema could conceivably be employed to do the same for temporally structured human subjectivity at the individual as well as the collective level. 
This would entail showing that the Kantian transcendental approach to the human subject requires complexification to do justice to something not anticipated by Kant: time (together with the rest of the transcendental apparatus of reason) is not merely the condition of the possibility of human subjectivity and its capacity for certain knowledge of and participation in a circumscribed phenomenal world (Deleuze's "perfect crystal"), but also, inescapably, of its impossibility. That is, multivalent possibilities of time itself condition the impossibility of a "pure" subjectivity that would guarantee certain knowledge of the world, mutual, intersubjective understanding and hence, a commonly shared and historically sustained "world". In short, Deleuze's "categories" of "time-crystals" enable one to formulate what might be termed a "quasi-transcendental" conception of the subject and of society: these "time-crystals" constitute both their conditions of possibility and of impossibility, or simply put, the insight that they are never actualisable as "pure" phenomena; they are always, given these complexly articulating temporal possibilities, "ruined" with regard to their actualisations (Deleuze's "crystal-seeds", "cracked" and "decayed" crystals).

\section{DELEUZE ON KANT'S REVERSAL OF TIME AND ON "TIME-CRYSTALS"}

To be sure, as anyone who is aware of what might be called the "Bergsonian strain" of Deleuze's notion of time would object, there is a much clearer line of continuity between Henri Bergson - who criticises Kant's notion of time mercilessly - and Deleuze than between Kant and Deleuze. That I readily admit; the only two important points I wish to make regarding Kant and Deleuze are, first, that there is an analogy or isomorphism between Kant's "reversal" of the relationship between movement and time (as understood by Aristotle), and Deleuze's theorisation of cinema (equally marked by a reversal of movement and time). Second, that Deleuze - and, one might add, before him Bergson - may be shown as following Kant in making time, or temporality, the very condition of possibility of human subjectivity, albeit accompanied by a fundamentally different understanding of time itself. To be more specific, in Kant's critical philosophy (1999), Deleuze captures what he regards as one of the great "reversals" in Kant's thought. This is encountered in Kant's first Critique, and Deleuze summarises it as follows (1999: vii):

...Time is no longer related to the movement which it measures, but movement is related to the time which conditions it: this is the first great Kantian reversal in the Critique of pure reason.

1 I am using "quasi-transcendental" here in the sense that it is employed by Geoff Bennington (1993: 276-277) with regard to Derrida's work, namely, “...in Derrida what makes possible immediately makes impossible the purity of the phenomenon made possible". 
Time is no longer defined by succession because succession concerns only things and movements which are in time. If time itself were succession, it would need to succeed in another time, and on to infinity. Things succeed each other in various times, but they are also simultaneous in the same time, and they remain in an indefinite time. It is no longer a question of defining time by succession, nor space by simultaneity, nor permanence by eternity. Permanence, succession and simultaneity are modes and relationships of time.

Just how radical Kant's reversal was, is evident from Deleuze's allusion to the eponymous Hamlet's remark that the time is "out of joint". Kant was responsible for dislodging time from the hinges that bound and subordinated it to movement, which, for Deleuze, opened up labyrinthine new possibilities, because if time changes, everything, including movement and space, changes. Paradoxically, the newly established primacy of time as that which must be presupposed by everything in the experiential world means that the simplicity of time's "straight line" is itself a labyrinth, as Borges suggests (Deleuze 1999: vii), in relation to which the ontological status of everything else has to be reconfigured. After all, as Deleuze claims in the passage cited above, "permanence, succession and simultaneity" are all fundamentally modifications of time for Kant (Kant 1929: 74-75); hence its labyrinthine mystery - how can the simple line of time, stretched between the past and the future, be the matrix of all these transformations?

It is as if Deleuze's Cinema 2 (2005) is a critical response to the enigma of time opened up by Kant's work in the $18^{\text {th }}$ century, ${ }^{2}$ albeit mediated by his reading of Bergson in this regard. It is worth recalling that Bergson (see for example 1910: 77-106 [particularly 100-101]; 232-240) criticised Kant for reducing time to space in terms of homogeneity and juxtaposition of discrete moments, instead of grasping the irreducible duration-character of time as a prerequisite for understanding qualitative multiplicity as a mutually interpenetrating stream of changing moments (rather than a quantitatively conceived succession), which also has far-reaching consequences for subjectivity (specifically freedom as an aspect of it, for Bergson). In Cinema 2 (2005: 80) Deleuze summarises Bergson's conception of time as follows (and its relevance for his own idea of time will become clearer below), simultaneously providing justification for my initial claim, concerning a link between Kant and Deleuze regarding time and subjectivity:

Bergson's major theses on time are as follows: the past coexists with the present that it has been; the past is preserved in itself, as past in general (non-chronological); at each moment

2 Although it is not my concern here, the same might be said of certain aspects of his earlier Difference and repetition (Deleuze 2004: 90-163), where he elaborates on three kinds or conceptions ("orders") of time, associated with Descartes, Kant and Nietzsche, respectively. As a friendly critic has reminded me, it is the latter of these three temporal orders (tied up with Nietzsche's notion of the "eternal recurrence") which is closest to Bergson's way of conceiving duration, the significance of which I hope to show. 
time splits itself into present and past, present that passes and past which is preserved. Bergsonism has often been reduced to the following idea: duration is subjective, and constitutes our internal life. And it is true that Bergson had to express himself in this way, at least at the outset. But, increasingly, he came to say something quite different: the only subjectivity is time, non-chronological time grasped in its foundation, and it is we who are internal to time, not the other way round. That we are in time looks like a commonplace, yet it is the highest paradox. Time is not the interior in us, but just the opposite, the interiority in which we are, in which we move, live and change. Bergson is much closer to Kant than he himself thinks: Kant defined time as the form of interiority, in the sense that we are internal to time (but Bergson conceives this form quite differently from Kant).

Ironically, although Deleuze's theorisation of time is clearly indebted to Bergson, the latter's own remarks on cinematography - for example where he disparagingly writes about "...the cinematographical habits of our intellect" (an allusion to his view, that cinema does not constitute true duration, but mere succession of discrete positions, creating the illusion of movement; Bergson 1922: 329) - do not meet with Deleuze's (1986: xiv; 1-11) approval, who sets out to redeem cinema in the most thoroughgoing fashion.

In Cinema 2 (2005: 66-94) Deleuze elaborates on what he calls four "crystals of time" - a striking and highly suggestive metaphor for distinct possibilities or "states" of the time-image in film. From his account it appears that different kinds of images merge in such a way that they condense, like shimmering crystals, the temporal relations or interactions among images of events and things preceding and succeeding or coinciding with their appearance. For Deleuze, this may be understood as the result of a direction followed in the history of cinema - one that suggests a promising alternative (2005: 66-67):

The cinema does not just present images, it surrounds them with a world. This is why, very early on, it looked for bigger and bigger circuits which would unite an actual image with recollection images, dream-images and world-images...Should not the opposite direction have been pursued? Contracting the image instead of dilating it. Searching for the smallest circuit that functions as internal limit for all the others and that puts the actual image beside a kind of immediate, symmetrical, consecutive or even simultaneous double...If we take this direction to its limit, we can say that the actual image itself has a virtual image which corresponds to it like a double or a reflection...the real object is reflected in a mirror-image as in the virtual object which, from its side and simultaneously, envelops or reflects the real: there is 'coalescence' between the two. There is a formation of an image with two sides, actual and virtual.

The "circuits" in question concern the temporal connections between specific images and others connected with them in terms of repetition (or identity), difference and simultaneity, for instance images of the mercurial Milena - now loving, accessible to her possessive lover, Alex; now elusive and tantalising - in Nicolas Roeg's Bad timing (1980). Despite their differences, images of Milena merge or amalgamate as if 
each has a virtual counterpart in the others, and relations between them approximate a state where one (or more) such image(s) condense(s) the pathways between them optimally, like a crystal. Accordingly, a "crystal" image is one where "the smallest internal circuit" between the actual image and its virtual counterpart is encountered. It concentrates different "slivers" or aspects of time in itself, for instance where the "circuit" between actual and virtual assumes the form of something like a site of/ for an exchange between the two kinds of image - an exchange which "....is all the more active when the circuit refers to a polygon with a growing number of sides: as in a face reflected on the facets of a ring, an actor seen in an infinity of twins" (Deleuze 2005: 68). Here Deleuze gives one the purest - which is to say the most "contaminated" - poststructuralist appropriation of cinema: in cases like these the actual and the virtual are "in continual exchange", which is to say that, while they are distinct from each other, they are "indiscernible", ${ }^{3}$ in so far as they continually merge into each other reciprocally (without arriving at a Hegelian synthesis; Deleuze also refers to it as an "uncertainty principle" in cinema). They are "mutual images" (Deleuze 2005: 67).

\section{TIME-CRYSTALS AS MODEL FOR SUBJECTIVITY AND SOCIAL HISTORY}

Here one can discern highly suggestive implications for the conceptualisation of human subjectivity. If a "crystal image" concentrates in itself all the possible relations between itself and its virtual counterparts, then the structure of subjectivity can be conceived of as a "crystal-function" (or -image) of temporal primacy in "circuitrelation" to subject-manifestations like actions and linguistic utterances. ${ }^{4}$ These

3 "Indiscernibility" may therefore be seen as the (cinematic-) interpretive poststructuralist counterpart of what Derrida calls "undecideability" in ethics. The latter concept suggests, not that one cannot or should not make moral decisions, but precisely that one cannot avoid making a decision in the end, albeit one issuing from carefully weighing all the relevant concerns, because there are no pre-programmed decisions available to us humans (Caputo 1997: 136137). Analogously, "indiscernible" images display a structure where, although the limpid and the opaque, for instance, can be distinguished, they have a curious "two-in-one" character, so that no precise separation of one from the other is possible; the specific aspect has to discerned in its "becoming-other" when it happens, unpredictably. This can further be broadened to include "indiscernible" subject-traits such as morally relevant actions, discussed below.

4 Deleuze and Guattari's criticism of Freudian psychoanalysis in Anti-Oedipus (1983) notwithstanding (see also Deleuze and Guattari 1987), Freud's (2011: 4667) own use of the metaphor of a "crystal" is further illuminating here, in the sense of something that condenses the structure of the human psyche such that, if the crystal should be damaged, or shattered suggesting psychically "damaged" subjects - one could learn more of the psyche, or crystal, as a whole. This has been called the "patho-analytic" principle in Freud's work (Van Haute 2013). It is the sense of a crystal as something highly condensed, but also potentially damaged or flawed, that resonates with Deleuze's understanding of it. 
would be themselves divisible into actual and virtual instances, such that (to take it a step further) distinctive subjecthood would be discernible in the most condensed instance, or "the smallest internal circuit" between temporal subject-actuality (the moment of acting, for example) and its virtual counterpart(s), such as past (and, in terms of the future anterior, future) actions that are consistent with the moment of subject-actuality. Furthermore, at the niveau of social history a parallel state of affairs would obtain: if individual human subjectivity is contemplated in "crystal-temporal" terms, then social history, which unfolds in time, could be grasped analogously by way of "crystallisations" of the social at specific junctures, along a trajectory of "internal-historical circuits". And just as the general structure of subjectivity is conceivable as an interplay between primary temporality and subject-constitutive manifestations like actions, social history, too, would stand in a tensile relation with historical events and movements, actual as well as virtual with regard to past and future.

To anyone familiar with Bergson's work, my reasoning here would probably resonate with Bergson's theorisation of what, in Deleuzian terms, is the relationship between virtuality and actuality (although I was not explicitly thinking of it at the time of writing), formulated by Bergson in Matter and memory (1911: 61-62) by means of the interlinking boundary between memory (that is, virtuality) and actuality (using the figure of an inverted "memory-cone", the apex of which touches the "moving plane" of actuality), and further theorised in Creative evolution (see particularly Bergson 1922: 1-8). Take this passage from Bergson (1922: 2), for example, as demonstration of the fact that my present theorisation of subjectivity along the avenues opened up by Deleuze's notion of time crystals, virtuality and actuality, is compatible with Bergson's in terms of duration, memory and perception:

...if a mental state ceased to vary, its duration would cease to flow. Let us take the most stable of internal states, the visual perception of a motionless external object. The object may remain the same, I may look at it from the same side, at the same angle, in the same light; nevertheless the vision I now have of it differs from that which I have just had, even if only because the one is an instant older than the other. My memory is there, which conveys something of the past into the present. My mental state, as it advances on the road of time, is continually swelling with the duration which it accumulates: it goes on increasing - rolling upon itself, as a snowball on the snow. Still more is this the case with states more deeply internal, such as sensations, feelings, desires, etc., which do not correspond, like a simple visual perception, to an unvarying external object. But it is expedient to disregard this uninterrupted change, and to notice it only when it becomes sufficient to impress a new attitude on the body, a new direction on the attention. Then, and then only, we find that our state has changed. The truth is that we change without ceasing, and that the state itself is nothing but change.

Conceivably one could carry out my proposed analysis in such Bergsonian terms, but the notion of time-crystals appears to me to be more than adequate for the task. The consequences of a complex elaboration of subjectivity and social history, like 
that which I am proposing here, are far-reaching. Instead of thinking of these, as is usually the case, as being articulated linguistically or symbolically (discursively), the introduction of the temporal here, not one-dimensionally but multi-dimensionally with regard to relations of "circuit-reciprocity", entails a layered or "laminated" notion of subjectivity and social history. By this I mean that subjectivity or social history conceived of as a "crystal" which constantly approximates the "smallest internal circuit" between actuality and virtuality would approach a condition, at least virtually, where multiple temporal or historical possibilities would lend themselves to possible actualisation. These, too, could be thought of as being "indiscernible", or subject to an "uncertainty principle" of sorts, not like cinematic images that "merge indiscernibly" with one another, but insofar as the actual and the virtual coalesce and feed into each other: actions (of a moral or political nature, for instance) are related to their virtual counterparts, both past and future, by way of a kind of circuitous interpenetration. That is, if there is consistency between actions performed at different times, their past and future virtual counterparts would approximate "the smallest internal circuit" in the form of a "crystal". If, however, there are discrepancies to a greater or lesser degree, the "circuit density" would deteriorate. "Consistency" should not here be construed as being the basis of predictability. The "indiscernibility" between the actual and the virtual at the level of action indexes the consistency between the actual and the virtual, but not the guaranteed, calculable future compatibility between them. This is analogous to the Derridean ethical concept of "undecidability", which does not mean (as some commentators evidently believe), that a decision cannot be reached because of some hesitation or "deconstructive vacillation", but rather that the unavoidable decision is not mapped out for agents in a kind of algorithmically precise, infallible manner, therefore requiring choice (Caputo 1997: 136-137).

To clarify what I mean by the analysis, above, of the relationship between the actual and the virtual, ${ }^{5}$ it is worth taking a closer look, at this point, at some of the distinctions Deleuze makes between "indiscernible" images, actual and virtual, which are constantly changing into one another without being separable (Deleuze 2005: 67-69)

5 It is impossible to do justice here to the relationship between the actual and the virtual regarding the rich spectrum of meanings and nuances of meaning pertaining to these concepts in Deleuze's ontology. I concentrate on those aspects that are pertinent to my own argument here. One should perhaps just note, in this regard, Boundas's observation (2010: 300): “In Deleuze's ontology, the virtual and the actual are two mutually exclusive, yet jointly sufficient, characterisations of the real. The actual/real are states of affairs, bodies, bodily mixtures and individuals. The virtual/ real are incorporeal events and singularities on a plane of consistency, belonging to the pure past - the past that can never be fully present. Without being or resembling the actual, the virtual nonetheless has the capacity to bring about actualisation and yet the virtual never coincides or can be identified with its actualisation". As Boundas continues to point out, this means that the relationship between actual and virtual is not linear, but reversible, as captured in the schema: "virtual/real < > actual/real < > virtual/real". As will be seen below, this clarifies the manner in which subjectivity may be comprehended in these terms. 
The indiscernibility of the real and the imaginary, or of the present and the past, of the actual and the virtual, is definitely not produced in the head or the mind, it is the objective characteristic of certain existing images which are by nature double...

...The actual image and its virtual image thus constitute the smallest internal circuit, ultimately a peak or point, but a physical point which has distinct elements (a bit like the epicurean atom) which are in continual exchange. When the virtual image becomes actual, it is then visible and limpid, as in the mirror or the solidity of finished crystal. But the actual image becomes virtual in its turn, referred elsewhere, invisible, opaque and shadowy, like a crystal barely dislodged from the Earth. The actual-virtual couple thus immediately extends into the opaque-limpid, the expression of their exchange. But it needs only a modification of conditions (notably of temperature) for the limpid face to darken, and for the opaque face to acquire or rediscover its limpidity. The exchange is started again. So long as the conditions are not made precise there is definitely a distinction between the two sides, but they are indiscernible.

Just as Deleuze can claim that some images are "by nature double", instantiating the "smallest internal circuit" and being "indiscernible" on this account, I would argue that in the realm of subjectivity (as well as social history) an analogous argument can be put forward, where a similar "exchange" could occur between virtual and actual aspects of subjectivity, for example in the form of actions. Such actions (for instance actions with moral import), where the virtual (past or possible future actions; "invisible, opaque and shadowy") can change almost imperceptibly into the actual ("visible and limpid"), and vice versa, could therefore also be termed "indiscernible", given the fact that their unpredictable, potential sliding into each other means the absence of precision. Yet there is nevertheless an undeniable distinction between the two classes of actions, as in the case of the indiscernible images that Deleuze discusses above.

What would be an example of a "crystal-function", on the part of a subject, regarding the temporal "circuitry" between actuality (actions, utterances) and virtuality (past and future actions, utterances), keeping in mind that I am not employing these terms in a manner that actualises the full spectrum of their significations in Deleuze's work (including his collaborative work with Félix Guattari)? The character of Shakespeare's (1994) Hamlet readily suggests itself as an instance where one can grasp "who Hamlet is" in terms of a kind of "virtual matrix" that generates, or is capable of generating, different actualisations. The words alluded to earlier (from Deleuze's reference to it): "The time is out of joint", can be taken as a sign of a kind of temporal short-circuit in the life of the (fictional) Prince of Denmark. Why? It is well-known that Hamlet returns from university when he is informed of his father's death, and his words serve as a reminder that his life, or world, has been "unhinged"; in other words, his distinctive subjecthood, immersed in time as the ambiguous condition of its "possibility and impossibility", has been disturbed, thrown out of kilter. But the "crystal" of his subjecthood (as singular instantiation of the general temporal structure of subjectivity) only really emerges in the wake of 
this catastrophic disturbance of his life, or temporal trajectory, when his conscience is activated by his suspicion that his father's death was "unnatural". Once his staging of the "play within a play" - where the treacherous murder of a king as he sleeps in his garden is portrayed - provokes the anticipated reaction from a clearly upset Claudius, the "circuit-relation" between Hamlet's successive actions (actualisations of virtualities) and their (past as well as future) virtual counterparts becomes apparent, incrementally constituting the distinctive time-crystal of his singular personhood. The temporal line between his suspicion that his father was murdered, his initial irresoluteness about the direction of his own actions (the "to be or not to be" soliloquy) and the course of action he decides on, is condensed into the crystal of "who Hamlet is", which can be articulated in terms of the interpenetration of actual and virtual temporalities. ${ }^{6}$

It appears, from this example, that one's distinctively personal subjecthood is likely to become salient under conditions where the ethical and aesthetic ${ }^{7}$ import of one's actions are foregrounded in "concentrated" form, that is, where they manifest themselves as a "crystal" of sorts. One might inquire what the relationship between virtual actions and performed actions is, which (in the case of time-crystal images in cinema) is described by Deleuze in terms of a "circuit-relation", suggesting that neither is primary in relation to the other. Although actual images may seem to enjoy primacy in relation to their doubles, or virtual images - where the latter would presuppose the former - a past virtual image as well as one in the future could in fact be presented as giving rise to present image-actualities, or, to use another cognate Deleuzian term, "percepts". This could happen through time-images that condense, crystal-like, the virtual possibilities of their actualisation, for instance an image of the sexually possessive Alex (in Roeg's Bad timing of 1980) gazing at the elusive Milena, at once recalling earlier, related, virtual images and prefiguring later virtual images of his lethal intentions, as he stares at her supine body. Is this also the case with time-constituted human subjectivity, or more particularly with the history of a concrete subject? At first blush it would also seem that a crystal-function cannot become virtualised unless concrete actions provide a clue regarding their virtual counterparts" "existence" and circuit-effectivity to begin with, and yet - thinking of the earlier instantiation of such a relationship in the character of Hamlet - is it not the case that the actuality of actions with ethical or political valence derives force from their virtual correlates? Like Husserlian temporal retentions (past in relation to the present) and protensions (future in relation to the present), virtual actions

6 A similar interpretation of Shakespeare's Richard the Third, or Thomas Hardy's Jude (the "obscure") is possible.

7 I am using "aesthetic" here in the Rancièrian sense, which does not relegate it in a modernist manner to an innocuous sphere, unrelated to the world of ethical and political actions; on the contrary, the aesthetic pertains to what Rancière calls "the distribution of the sensible", that is, the manner in which the perceptible world is structured or stratified along lines of hierarchical or egalitarian power relations (Rancière 2013; Tanke 2011: 49-50). 
exercise their crystal-effectivity in ethical or aesthetic terms in relation to a moving "present" of subject-actions from the perspective of future possibilities and past actions. Hence, from the perspective of Hamlet's "to be or not to be" monologue his earlier as well as his later actions gain intelligibility as well as moral and aesthetic coherence - his scepticism regarding the putative ghost of his father's exhortation, that his "murder" be avenged, or his decision to stage a play (within the play) to bait Claudius (the murderer), for instance.

\section{DIFFERENT TIME-CRYSTALS IN FILM}

It should be clear from the preceding argument that a cinematic "crystal" is simultaneously a metaphor and a concept that enables viewers or interpreters to detect threads of meaning along the trajectories marked by the reciprocal exchange between actual and virtual images which, furthermore, need not be limited to images reflected in mirrors, shiny surfaces or, literally, crystals in film (Deleuze 2005: 6873). Moreover, although the metaphor of "crystals" is employed by Deleuze in Cinema 2 specifically to scrutinise temporal aspects of cinema that are brought into view by its hermeneutic fecundity, as the previous section shows, its fruitfulness is not restricted to cinema, but can be extended to other fields of inquiry, in this case time-oriented human subjectivity and, as I intend arguing below, social history. To be able to do so, one has to take a closer look at the different types of "time-crystals" distinguished by Deleuze.

Deleuze (2005: 80-94) elaborates on four different kinds of "time-crystals" time-images functioning like crystals in the manner described above - pertaining to the films of directors Max Ophüls, Jean Renoir, Federico Fellini and Luchino Visconti, respectively. Briefly, Deleuze finds in Ophüls's films "complete" or "perfect crystals", with characters "incarcerated" in crystalline totalities of some kind. These obviate the possibility of an exterior, in this way reminding one of the Eagles' song, Hotel California, where the doorman tellingly says that “...you can check out any time you like, but you can never leave". ${ }^{9}$ It also resonates with the ending of the novel, American psycho (Easton Ellis 1991), where the anti-hero, Bateman (a play on "Batman"?), is confronted with a sign above a door in a club

8 A critic has reminded me that these four kinds of time-crystal are not the only ones that Deleuze identifies, although he concentrates on them, and further that the number of such crystals is "openended". Deleuze (2005: 73) also refers to the "turning crystal" in Tarkovsky's films, for instance, and one can discern something different ("the red crystal") in his discussion of Herzog's Heart of glass, too (2005: 72).

9 It is not only in Ophüls's films that one encounters this, of course. Chaplin's Modern times (1936), with its depiction of a society subject to pervasive disciplinary power, comes readily to mind (Olivier 2012), as does Winkler's The Net (1995), where the protagonist discovers that, unless one's "identity" is registered within the encompassing electronic network comprising the "social domain", one finds oneself in a paradoxically non-existent "outside". 
that reads: "THIS IS NOT AN EXIT"; a reminder that, when the reader puts the book down, she or he is still, inescapably, incarcerated in the ostensibly (but by implication encompassing, real) "fictional" world constructed in the novel. Renoir's films, in turn, teem with crystals of various kinds (Deleuze 2005: 82-83), with the difference that, instead of faultless crystals, his films always display a crack or flaw, which functions as possible escape route for characters who are capable of rising above the constraints of a certain "time". ${ }^{10}$ The "third state" of the crystal - one in the process of "formation and growth" through crystallisation "seeds" - is associated with Fellini by Deleuze (2005: 85-86). "Entrances" of various kinds (urban, psychic, historical) are encountered in Fellini's films, and they serve to constitute the crystal as something expanding, yet accessible via various avenues which are themselves like "crystalline seeds". ${ }^{11}$ Deleuze's fourth cinematic crystal-condition pertains to the work of Visconti (Deleuze 2005: 91-93), and revolves around the crystal in a temporal or historical process of decomposition or decay, as encountered in his films. ${ }^{12}$

My purpose here is not to explore the fecundity of Deleuze's four kinds of crystals in cinema, however, but to extend this to the question of human subjectivity and social history. Deleuze (2005: 80) himself provides justification for such an extension where he remarks, apropos of Bergson's conception of time: "But, increasingly, he [Bergson] came to say something quite different: the only subjectivity is time, nonchronological time grasped in its foundation, and it is we who are internal to time, not the other way round...Subjectivity is never ours, it is time, that is, the soul or the spirit, the virtual. The actual is always objective, but the virtual is subjective..." (Significantly - in light of my earlier argument concerning Kant, Deleuze and time - Deleuze proceeds to remark, on the same page, about the fact that "Bergson is much closer to Kant than he himself thinks".) Keeping this in mind, and extending it towards cinema, it is important to note that the "split" or tension between two

10 Again, there are many other examples of this in cinema, for instance in Footloose (Ross 1984), where the cracked crystal is evident in young people's counter-authority embrace of dancing, which subverts or escapes from the institutional rule of the church (Olivier 2012).

11 In addition to the films discussed by Deleuze, The sea inside (Amenábar 2004) may be seen in terms of this kind of crystal-interpretation: the quadriplegic Ramón imaginatively projects himself through "crystal seeds" of fantasy or memory as "entrances" into a past where he was still completely, sensuously, alive and mobile - this is the eponymous "sea inside". Like the Rome in Fellini's Roma, the latter is never complete, but infinitely capable of expanding through Ramón's memories (Olivier 2012).

12 The "crystalline environments" constructed in Visconti's films are exposed as being hollowed out from the inside with the passing of time, for instance those of the aristocracy in his The leopard. One can detect a comparable process in Dirty dancing (Ardolino 1987), where the "crystalline environment" of America's self-made wealthy classes is uncovered as dissolving from within through the exchange between images of its waning virtual force and those of the actual, erotic power of the young dancing bodies (Olivier 2012). 
cinematic images - the actual and its "other", the virtual - is a significant trope for the exploration of subjectivity and social history in temporal or historical terms, because, as Deleuze indicates, the split in question (for example in the case of the vaunted "perfect crystal", where it exposes "hidden fault lines") is a symptom of the persistence of time, which is always already riven (Deleuze 2005: 81). Hence, what Deleuze calls "crystals of time" (2005: 66-94) - convoluted time-lines that point forward and backwards, or condense circularities and repetitions of various sorts - enable one to trace the trajectories of time concentrated in cinematic imageclusters. In the process they connect past events, as well as past-event alternatives not activated ("virtualities" or latencies; not in the sense of "virtual-" or "cyberspace"), with present actualities and future possibilities. ${ }^{13}$

\section{CRYSTALS OF TIME AND SOCIAL HISTORY}

In this section I shall concentrate on the relevance of Deleuze's figure of "timecrystals" for social history, having already briefly elaborated on its pertinence for understanding subjectivity. As argued earlier regarding its facilitation of the comprehension of subjectivity as thoroughly temporal, I believe the notion of timecrystals is equally valuable for a richer understanding of social (including political and economic) history. It will be recalled that, earlier, it was suggested that individual human subjectivity can be thought of in "crystal-temporal" terms, which would then imply that temporally-unfolding social history could be grasped similarly by way of salient "crystallisations" of the social at specific moments along the defiles of "internal-historical circuits". It was further proposed that the conception of the structure of subjectivity as an interplay between primary temporality and subjectconstitutive manifestations like actions, could be transferred to social history, which would therefore entail a complex relation between the social (including the political and economic) - specifically as instantiated in distinct, "crystalline" form in different social-historical contexts, as will be argued below - and relevant historical events, actual as well as virtual with regard to the past and the future.

Furthermore, the four types of time-crystal distinguished by Deleuze add another dimension to this. If this is the case, then, social history can be approached by way of finding there signs of temporal or historical "crystal-functions" that may

13 Following Lyotard, this could also be articulated, on a specific historical scale, as "Rewriting modernity", that is, approaching history in such a way that all the dead-ends, calamities and traumas of modernity may be endlessly, interminably "worked-through", with a view to overcoming their continuing "nachträgliche" hold on contemporary society and culture (1991: 24-35). Although Lyotard borrows this concept of "working-through" from Freud (of whose "Oedipus" Deleuze and Guattari are severely critical), the resemblance here lies in the repetition, or tendency to repeat, past virtualities endlessly on a historical circuit instead of, by working-through them (as a work without end), opening new possibilities or virtualities. 
cast light on the relationship between "actual" and "virtual" events - that is, events that have indeed occurred, but, like a cinematic image, stand in a "circuit-relation" to their virtual counterparts in the past as well as the future. What does this mean? First, it implies that both actual and virtual events are characterised by contingency, as opposed to necessity. In the case of historically actual and actualised events the contingency is factual (or "factical", as Heidegger might say), while the contingency of virtual events, past and future, is of the order of possibility. Moreover, there is a circuit-relationship between these. To be able to focus on specific historical incarnations of the social, recall the earlier claim that distinctive subjecthood could be perceived in its most concentrated guise as "the smallest internal circuit" between temporal subject-actualisation (for instance specific actions) and its virtual correlates, such as already actualised or past (and, in terms of the future anterior, projected future) actions that are consistent with the "time-crystal" of singular subjectivity. Just as this formula enables one, as briefly argued above, to understand a character such as Shakespeare's Hamlet in terms of the "crystalline" temporal structure of his subjecthood, it can, I believe, be enlisted in an attempt to grasp the "crystalline temporality" of distinct social phenomena or formations. The historically instantiated social (economic, political) condition that will be considered by means of Deleuze's four kinds of time-crystal is neoliberal capitalism, and a comparative approach via the notion of the "time-crystal" will be adopted. Keeping in mind what was said earlier regarding time as being "quasi-transcendental" - that is, as being the condition of possibility of events and actualities, while simultaneously also being the condition of their "impossibility" or "ruin" - the interpretive matrix of the following analyses or interpretations is inimitably formulated by Deleuze as follows (2005: 95):

What the crystal reveals or makes visible is the hidden ground of time, that is, its differentiation into two flows, that of presents which pass and that of pasts which are preserved. Time simultaneously makes the present pass and preserves the past in itself. There are, therefore, already, two possible time-images, one grounded in the past, the other in the present. Each is complex and is valid for time as a whole.

\section{NEOLIBERAL CAPITALISM AS SOCIAL INCARNATION OF THE "PERFECT CRYSTAL"}

What would be an example of a "perfect crystal" in social terms, that is, as a social formation that would not admit of any escape because it is predicated on the temporal or historical impossibility of an "outside"? Plato's ideal republic may be considered a fictional-philosophical instance of this, given its exhaustive mapping of the community (polis) according to classes corresponding to the parts of the human soul or psyche, namely reason, spirit and appetite. According to Plato (1991) in the Republic, these classes - to one of which every citizen belongs - 
comprise the rulers (guardians or philosopher-kings), the protectors (soldiers and navy) and the producers (commercial classes). These are the social conditions for "justice", conceived of as harmony among the different classes, where such a state corresponds to "justice" in the individual soul: when a person's reason rules over desire with the help of spirit, so, too, a polis (or society) is "just" or harmonious when the guardians rule wisely according to reason, with the courageous support of the (spirited) protectors, keeping the sometimes disproportionate appetites of the commercial classes in check. If appetite or spirit should become dominant in the polis, a city is soon in disharmony, especially if reason (the rulers) is taken in tow by the wish on the part of the people to satisfy their needs uncontrollably. Where is the flawless time-crystal in this state of affairs? It appears precisely where time has been domesticated by "rational" design. Instead of a tension between actuality and its virtual other, in Plato's utopian state they coincide perfectly, leaving no room for social and political nuances or "laminations" generated by the "smallest internal circuit" between virtuality and actuality. In any state where time and history are not put in chains, such a minimal relational circuit is constantly approximated, asymptotically, but never attained, because - as in the case of virtual images in the cinema of the time-image - multiple historical or temporal possibilities would be "virtually" available for possible actualisation. That such a state would be dystopian, rather than utopian, is arguably self-evident, given the inescapability of time, which, as Deleuze shows, is always already divided.

But surely the neoliberal state is nothing like Plato's "flawless", fictional polis? Of course not, in actuality. But when one takes a closer look at it, the way that it is conceived in "virtual terms" bears a surprising resemblance to a flawless crystal. In fact, one gets the distinct impression that people who regularly allude to capitalism's ostensibly guaranteed capacity to enrich every member of society, without exception, have in mind a failsafe formula which supposedly functions in a vacuum, where the generation of income is endlessly determined by the incorruptible "laws" of supply and demand. This is its "utopian" character, which, like Plato's model, has banished time, suggesting that there is, at least in principle, no gap between the virtual and the actual, and hence that it represents a "perfect" crystal. Here, too, one can already detect dystopian signs, insofar as time is always already split - the dream of a perfect, incorruptible circuitry between the actual and the virtual is inescapably shattered by the intrusion of time in social reality.

It is not difficult to tell what economic theory is responsible for this notion of the neoliberal economic model. The signature of Friedrich Hayek and the Chicago School of Economic Theory is unmistakable here (Klein 2007: 4-6; 49-57). Ultimately deriving from Adam Smith's laissez-faire economics, the economic theory taught by Hayek and Milton Friedman, the chief luminary of the Chicago School, is a form of capitalist purism (hence the "flawless crystal"-resemblance), according to which any kind of regulation or interference in the putatively "natural" process of capitalist 
production and consumption is tantamount to a kind of economic sin - even the language used by adherents of this theory reflects its quasi-religious, ideological status: one of the school's founders, Frank Knight, described theory in this context as a "sacred feature of the system". According to Hayek, Friedman, Knight and others belonging to the Chicago School, if allowed to be the sole force regulating the economy, the "market" would determine the production of exactly the "right" products, in the right quantities, at the right prices, affordable by workers who are paid exactly the right wages. It painted a veritable economic paradise of employment for all (under the "right" circumstances), where not even inflation would destabilise the system. Unfortunately for its adherents, however, the vaunted flawlessness of the crystal at the heart of neoliberalism amounts to a denial of time and history, unlike the economic system with Keynesian credentials, which acknowledges the timebound operation of economic relations through its emphasis on the need for state intervention in economic processes.

As pointed out by sociologist Daniel Bell, neoliberal capitalism's infatuation with an idealised system, which he compares to "a celestial clockwork", is the hallmark of "radical free-market economics" (quoted in Klein 2007: 51). In regarding this system as something that could actually exist in pure form, instead of always (unavoidably) being affected by factual, temporally contingent and therefore unpredictable conditions in social reality, its adherents remind one of medieval believers in the fanciful astronomical system of crystalline spheres, supposedly existing, one within the other, and on the innermost one of which (the Earth) humans supposedly lived. As Klein shows, Friedman and his cronies could not find any historically existing economy in social reality that provided confirmation of the hypothesis that, if all "distorting" factors (like government interference in economic processes) were removed, the hallowed market could, god-like, create economic heaven on Earth. This also means that, like religious fanatics, dogmatic neoliberal economists are in a position where they cannot be disproved: whenever there is something wrong with an economy (for example high inflation or stubborn unemployment), it is "proof" that the market is not truly free, given the principle that the unhindered centrality of the market is synonymous with "freedom". Such vaunted "freedom" - that is, the perfect, mathematically modelled free market system - could only exist in abstraction; not in time-soaked social reality.

As far as its "perfect crystal" status is concerned, implicitly claimed by the neoliberal capitalist model, it is clear that, instead of acknowledging the historical distance between the actual "image" of its functioning in the social sphere, on the one hand, and its virtual counterpart, on the other - which would entail a relation of temporal layers or "laminations" between them - it prioritises the virtual at the cost of the actual (economic events in social history), in this way effectively denying any temporal "circuit" between them. In cinema this is not an unconscionable situation - it is conceivable that even ostensibly "actual" images be treated in such a manner 
that they are "virtualised", in this way allowing the film to exemplify a temporalontological assessment of social reality. This is arguably the case in Alain Resnais's (1961) Last year at Marienbad, where the unfolding of "actual" images amounts to a catalogue of "timeless" virtualities: "last year" is repeated, "identically", dreamlike, ad infinitum. Even in poetry this is encountered, as in the "timeless" images comprising W.B. Yeats's Sailing to Byzantium. ${ }^{14}$ The paradox here is that in both instances the artwork - film and poem - suspends time, but can only do so within time itself. Hence their aesthetic reduction of historically framed social reality, through the use of a specific relation between actual and the virtual images, is itself vitiated by its dependence on the divisibility of time. Cast in (neoliberal) economic terms, however, such vitiation - made possible by the "partitioning of the sensible" in art, as in politics (Rancière) - has concrete social and historical consequences, as Klein (2007) shows in graphic detail. In other words, far from embodying a perfect, flawless crystal, neoliberalism always already harbours a "flawed" crystal (or "pearl", perhaps ${ }^{15}$ ) within its innermost being, in more than one sense, as I shall argue below.

\section{NEOLIBERAL CAPITALISM AS SOCIAL INCARNATION OF THE "FLAWED CRYSTAL"}

It is beyond doubt, as Karl Marx recognised and many other thinkers have since confirmed (e.g. Kovel 2002: 5), that capitalist economic relations bring untold wealth for some (the capitalists), although arguably untold misery for others (the proletariat). In the early $21^{\text {st }}$ century this economic and social chasm has grown even wider, with the expression, "the $1 \%$ versus the $99 \%$ " capturing the extent of the economic gulf separating the rich from the poor today. This is already sufficient to justify the claim that capitalism represents a "flawed crystal", instead of a perfect one, as neoliberal theory might suggest. But there is a more fundamental reason why this is the case, and Marx provides the conceptual means to grasp capitalism's flawed character where he remarks in the Grundrisse, apropos money as the embodiment of exchange value (Marx 1972: 59):

14 Such "timeless" images include those conjured up by these lines in W.B. Yeats's poem:

"Consume my heart away;

sick with desire

And fastened to a dying animal

It knows not what it is; and gather me

Into the artifice of eternity."

15 If one considers that a pearl grows within the soft folds of molluscs such as oysters, adding accretion upon accretion on and around something hard (like a grain of sand) that has penetrated into the oyster's mantle, then the "pearl" of capitalism seems to be an appropriate metaphor for this shiny, crystalline, but ultimately ecologically harmful entity within the "flesh" of society. 
The definition of the product as exchange value necessarily entails that the exchange value leads a separate existence, severed from the product. This exchange value which is severed from the commodity and yet is itself a commodity is - money. All the properties of the commodity viewed as exchange value appear as an object distinct from it; they exist in the social form of money, quite separate from their natural form of existence.

This is not all there is to it, however. Whereas in traditional societies the social bond binding people together concerned mutual dependence and the use-value of objects, under capitalism such social dependence has been reduced to exchange value, which further comprises the ground for individuals exercising power over others, simultaneously denying all genuine particularity and individuality (Marx 1972: 66). Small wonder Marx can comment (1972: 66):

The social character of activity, and the social form of the product, as well as the share of the individual in production, are here opposed to individuals as something alien and material... The general exchange of activities and products, which has become a condition of living for each individual and the link between them, seems to them to be something alien and independent, like a thing.

The alienation that occurs between people and the products of their labour under capitalism therefore also entails the alienation between individuals themselves, whose "personal power" has been reduced to "material power" linked to the exchange value that they command. This is the true flaw in capitalism: not merely that it drives a wedge between people by means of asymmetrical accumulation of wealth, but also, and more significantly, that it alienates individual subjects from the intrinsic or usevalue that material things could have for them - a comfy old sofa, an old grandfather clock - and concomitantly from an axiologically variegated world as well as from other people whose personal (relationship-) value has surreptitiously become subject to exchange value.

In terms of Deleuze's time-crystals one might say that exchange value, quantitatively expressed as money, is the virtual counterpart of actual values, intrinsic (as in the case of a "love-object") or utilitarian, and that the temporal circuit between them always approximates the "smallest internal circuit", with the actual constantly being transmogrified into the virtual, but without this state ever being fully attained, given the fact that the actual has the countervailing tendency, always to reassert its intrinsic or use-value. This tendency, which is symptomatic of the other meaning of a "flawed crystal" - namely that the flaw or "crack" (in this case the flaw of alienation) comprises a "way out of the crystal" - is itself anchored in the temporal "pearl", or hard crystalline core of capital, embedded in the "soft flesh" of human society as a kind of irritant element giving rise to the formation of the lustrous "pearl". It manifests itself in phenomena such as the inception and growth of diverse social movements, in response to economic crises caused by or within capitalism, such as the 2008 global financial crisis, which has given rise to a number 
of significantly anti-neoliberal cultures, including the Occupy Wall Street movement (Castells, Caraca and Cardoso 2012). Such movements widen, rather than lessen, the distance between the virtual and the actual axes of capitalism's time-crystal, and they play themselves out in the form of a "fluctuating internal circuit" between these extremes - a "circuit", moreover, that appears in concrete social and historical phenomena.

With regard to the question of alienation under capitalism it should be noted that, as a benevolent critic has pointed out to me, more recently someone like Maurizio Lazzarato (see Lazzarato in list of references) has published interesting analyses on new forms of the organisation of work (labour). Lazzarato focuses on so-called "immaterial labour" - "which is defined as the labor that produces the informational and cultural content of the commodity"; that is, the kind of work not usually acknowledged as such, like communication and activities involved in establishing cultural standards. The result has been that "labour" has been intellectualised, as may be perceived in the communication technologies of today, which require "subjectivities rich in knowledge" (Lazzarato n.d.). But while this new form of work, which requires of workers to "activate and manage productive cooperation" (Lazzarato n.d.), may have raised expectations of more egalitarian relations between managers and workers, (predictably) this is not the case (Lazzarato n.d.):

The new slogan of Western societies is that we should all 'become subjects'. Participative management is a technology of power, a technology for creating and controlling the 'subjective processes'. As it is no longer possible to confine subjectivity merely to tasks of execution, it becomes necessary for the subject's competence in the areas of management, communication, and creativity to be made compatible with the conditions of 'production for production's sake'. Thus the slogan 'become subjects', far from eliminating the antagonism between hierarchy and cooperation, between autonomy and command, actually re-poses the antagonism at a higher level, because it both mobilizes and clashes with the very personality of the individual worker... The subject becomes a simple relayer of codification and decodification, whose transmitted messages must be 'clear and free of ambiguity', within a communications context that has been completely normalized by management. The necessity of imposing command and the violence that goes along with it here take on a normative communicative form.

From this it should already be apparent that, far from having erased the alienating conditions between individuals described earlier by Marx (because today labour has been "intellectualised" and workers are encouraged to engage in "productive" communication), alienation has been elevated to a higher level, as it were. Lazzarato (n.d.) explains:

The management mandate to 'become subjects of communication' threatens to be even more totalitarian than the earlier rigid division between mental and manual labor (ideas and execution), because capitalism seeks to involve even the worker's personality and 
subjectivity within the production of value. Capital wants a situation where command resides within the subject him- or herself, and within the communicative process...In fact, employers are extremely worried by the double problem this creates: on one hand, they are forced to recognize the autonomy and freedom of labor as the only possible form of cooperation in production, but on the other hand, at the same time, they are obliged (a lifeand-death necessity for the capitalist) not to 'redistribute' the power that the new quality of labor and its organization imply. Today's management thinking takes workers' subjectivity into consideration only in order to codify it in line with the requirements of production. And once again this phase of transformation succeeds in concealing the fact that the individual and collective interests of workers and those of the company are not identical.

In other words, the "flawed crystal" of capitalism manifests itself again in the stubborn reassertion of the distance separating the virtual and the actual. Here it assumes the form, not merely of the impossibility of closing the gap between the actual (the newly valorised, ostensibly egalitarian, communication-oriented labour relations) and the virtual (the unequal distribution of financial-economic power between workers and management), but also in the (for capital necessarily) flawed conception of communication that pervades the productive process. While the embodiment of immaterial labour in communicational work carried out by subjects "rich in knowledge" might seem to imply a high degree of equality on the part of those involved - managers as well as workers - this is not at all the case. As Hardt and Negri (2006: 111) point out, it is precisely under conditions of "immaterial labour" that workers experience extreme alienation, given the incompatibility between the qualitative nature of the work they are doing and the exploitative economic relations that unavoidably obtain where "hierarchy and command" are not lessened, as one might expect.

There is another reason why the virtual and the actual of capitalist temporality can never coincide completely, as evident from the counter-substantialist thinking of Anti-Oedipus (1983). It concerns the tension between what Deleuze and Guattari call capital's "deterritorialising" andits "reterritorialising" functions. "Deterritorialisation" here appears to entail the destruction of the stasis that accompanies "identification" or substantialist thinking of all kinds, and concomitantly the liberation of what they call the process of "desiring-production". It accompanies the "decoding" of flows and contrasts with "reterritorialisation", which is claimed to "arrest the process" of desiring-production (Deleuze and Guattari 1983: 382), where the latter comprises the fundamental ontological structural dynamic, instead of the traditional Westernphilosophical denial of temporal process. As such, deterritorialisation is part and parcel of what they understand by the task of "schizoanalysis" (1983: 316), which is aimed at freeing desiring-production. At first blush this seems to suggest that capitalism promotes a schizoanalytic freeing of productive powers, and in a sense it does, but this is only one aspect of its functioning. In fact, capitalism turns out to be paradoxical: through its mode of production it engenders an impressive 
"schizophrenic accumulation of energy", but at the same time also "vast powers of repression" (Deleuze and Guattari 1983: 34) in relation to the very limit of schizophrenic production that it promotes. By replacing the idea of a code with money, in this way creating "an axiomatic of abstract quantities" (p. 33), it characteristically "decodes" flows of desiring-production of all kinds, in this way "deterritorialising" the socius (the principle upon which society is based, at any given time), for the optimisation of production. However, it also "recodes" and "reterritorialises" these in symbolic and imaginary ways (p. 34). Hence capitalism comprises the ceaseless alternation between productive flows and the "violent, artificial" imposition of limits and boundaries. This ambivalence at the core of capital therefore comprises its production-promoting tendency, consisting of decoding and deterritorialisation of productive flows, on the one hand, and its countervailing inclination of artificial reterritorialisation, on the other, by means of "its ancillary apparatuses, such as government bureaucracies and the forces of law and order" (Deleuze and Guattari 1983: 34-35).

The temporal implications of this become clear in light of the following. The "schizophrenic" side of capitalism, which represents becoming, or what one might term "becoming-time", can never exist in its purity, unfettered by the return of those very social and legal practices that undercut and hamper its "schizophrenisation" of social and economic life, which arrest the forces of becoming. What Deleuze and Guattari characterise and valorise as the flows of desiring-production that make the extraction of surplus value possible, promoted by one aspect of capitalism's functioning, come up against an inexorable barrier in the shape of capitalism's other, repressive side, without which it cannot entrench itself, and which, furthermore, "absorbs" surplus value. In terms of the actual and the virtual as "images" of time, this amounts to a "circuit" between actuality (productive flows) and virtuality (arresting the flows), which can never coincide completely. At the same time, as sign of a "flawed" crystal, this points to "a way out of the crystal" insofar as "deterritorialisation" can, and should, become self-reflexive: the deterritorialisation must, in turn, be deterritorialised. How is this to be achieved, considering that capital's drive to deterritorialise every aspect of social experience is aimed at maximising profit? To turn this drive against itself would surely undercut its capacity for profitgeneration, it would appear. Whether or not this is the case, the self-reflexivity in question can be explained as follows.

It is not difficult to compare what Deleuze and Guattari call "deterritorialistion" to what the economist, Schumpeter (borrowing from Nietzsche), labelled the "creative destruction" which accompanies capitalism (Harvey 1990: 17). Given the evidence, accumulating daily, that capitalism is the main culprit driving eco-destruction (more on this below), today it has earned for itself the related, but more dubious epithet of "destructive creation", where the first part of this oxymoron may be taken as 
referring to its effects on natural ecosystems, and the latter part to the creation of financial wealth. In short, capitalism has turned out to have a Midas touch regarding life on the planet; hence the need for "deterritorialising capital's deterritorialisation", to be able to initiate a time-circuit that promises a way out of the cracked crystal of capitalism. In other words, a process of "schizoanalysis" of capital has to replace the usual relationship between deterritorialisation and reterritorialisation, where capital itself would be freed from its inherent tendency to colonise the social and the natural world in the course of this process (to set them up for capitalist economic production). Concomitantly, this "double-deterritorialisation" would "let humans be humans and the Earth be an Earth" (to use Heideggerian phraseology) by scrupulously avoiding forms of capitalist development that would further damage social and natural ecosystems, and if necessary, "free capitalism from itself". This would allow time for nature's resilience to display itself before the very roots of such resilience have themselves been destroyed, and therefore it contains the promise of a new lease of life for social history.

\section{NEOLIBERAL CAPITALISM AS SOCIAL INCARNATION OF THE "CRYSTAL OF SEEDS"}

It will be recalled that, in cinema, Deleuze casts the "crystal of seeds" temporally as infinitely expanding through various "seeds", or entrances and exits. This picks up the thread generated in the previous section by the idea of a "crack" that could function as escape route from an otherwise totalising time-crystal, understood here as "temporal seeds" located within the crystalline pearl of capitalism itself. As such, they comprise the historical, virtual potential (hence, "seeds") at the heart of capital as economic system, available for actualisation in an unspecified future. In light of what was argued above, these seeds could germinate historically into something that would allow for self-reflexive liberation of the deterritorialising tendency of capital from its unavoidably destructive colonisation of social and natural ecosystems - an ineluctably damaging process, given the self-evident impossibility of future limitless economic growth in a finite planetary ecosystem. To understand what is at stake here, recall Bergson's (1911: 61-62) schema of the virtual "memory-cone" interacting with the "plane" of actuality - the crystal seeds in question here correspond to everything that is virtually, or latently, contained in the memory-cone, and which could conceivably be actualised at some historical point in time.

One such instance of a simultaneously virtual and, to a limited extent, actual "crystal of seeds" regarding capitalist practice is articulated by Thomas Princen in his book, The logic of sufficiency (2005), where he argues convincingly in favour of an economic "logic of sufficiency", as opposed to a "logic of excess", both of which represent virtual and actual instances of capitalist economic practice, the latter corresponding to the present neoliberal model predicated on "excessive" growth. In 
addition to drawing attention to the long-term consequences of these two distinct economic "logics", Princen discusses actually existing instances of communities and companies that practise the "logic of sufficiency" in relatively small enclaves. These are located within a surrounding world where the vast majority pursues the "logic of excess" as if limitless economic growth were possible, that is, as if natural resources were infinite, and are, furthermore, impervious to the kind of ecological abuse inflicted on them by homo economicus. Against the backdrop of a discussion of companies and communities that defy the odds by resolutely living according to the "logic of sufficiency" - in this way actualising the virtual seed buried in the crystal of capitalism - he observes (Princen 2005: 5):

An urban neighbourhood eschews the car, a timber company holds back on its harvests, two industrial countries find that treated sewage is enough, persistent toxics too much, and [an] international society bans ozone-depleting substances. Unusual cases, perhaps, but rather sensible, one might think. A similar story can be told about lobster fishing in Maine and, no doubt, about countless other practices in countless other places, in North America, Europe, and other 'advanced industrial countries'. Each instance may represent a trivial portion of that country's overall economy. But the 'advances' of these economies - the technologies, the stock markets, the transportation and communication systems, the conveniences and time-saving devices - represent something else, namely, ever-increasing throughput of material and energy. That throughput - the extraction of resources, the manufacture and use of products, and the disposal of wastes - supports, and now threatens to undermine, those very economies. Such throughput cannot be sustained. So these instances of sufficiency may be trivial by conventional measures - municipal budgets, industry outputs, gross domestic product, trade flows, stock market indices. But they are harbingers of a different economy, I contend, one that puts ecological and social constraint with a long-term view at the centre of economic and political life.

Princen reminds those resistant to the idea of sufficiency in the place of excess that it does not mean that people have to give up the hope of "thriving". In fact, he argues - with many telling examples to support his claims - unless we switch from the present logic of excess to the logic of sufficiency, our descendants are almost certain not to thrive in the future, because of depletion of resources and irreversible damage done to the natural environment. Living according to the principle of economic sufficiency would amount to this, according to Princen (2005: 7):

Sufficiency as a principle aimed at ecological overshoot compels decision makers to ask when too much resource use or too little regeneration jeopardizes important values such as ecological integrity and social cohesion; when material gains now preclude material gains in the future; when consumer gratification or investor reward threatens economic security; when benefits internalized depend on costs externalized. 
If the seed of economic sufficiency were to be cultivated, allowing it to germinate incrementally, as in the case of the companies he discusses as paradigms of the "logic of sufficiency", people can, indeed, thrive in the future on this planet. ${ }^{16}$

Another perspective on the possible actualisation of such virtual "seeds" within capitalism itself is afforded by Joel Kovel (2002). However, "virtual seeds" should here be construed as being buried very deep in the historical crystal of economic activity, beyond the level where the recognisable roots of capitalism penetrate (but still sharing in the historically evolved "genetic material" from which capitalism developed), because Kovel $(2002: 6 ; 141-144 ; 149)$ is adamant that capitalism as such is un-reformable in the light of being predicated on limitless economic growth. Therefore, given the constant "degrading of the conditions of its production", such as putting unbearable pressure on natural resources, aiming for low worker wages, and neglecting maintenance of the means of production, capitalism should be replaced, Kovel contends, by ecosocialism. The latter would be something different from all historically actualised socialisms, and is formulated in unavoidable exploratory and speculative terms. (For Kovel's full account, see especially 2002: 222-232; 238-244.) Succinctly put, the actualisation of these specific "virtual seeds" would entail the incapacitation of capital by changing the ownership of "productive resources" from private to public, in this way freeing human productive capacity from exploitation by capital in a "free association of producers". Kovel adds something new to these essentially Marxist provisions by insisting that they should be accompanied by the practice of an "ecological politics" that is "prefigurative and interstitial", starting with contingent, random "ecological ensembles", such as an activist group intervening on behalf of homeless people, a permaculture project, or a neighbourhood utilising open city spaces for food production (Kovel 2002: 225). This procedure would be "prefigurative" in the sense of joining and interconnecting such ensembles incrementally and gradually, with the aim of their eventual amalgamation into broader eco-totalities. Only then could capitalism be challenged successfully. Kovel puts it this way (2002: 10):

The term ecosocialism refers to a society that is recognizably socialist, in that the producers have been reunited with the means of production in a robust efflorescence of democracy; and also recognizably ecological, in that the "limits to growth" are finally respected, and nature is recognized as having intrinsic value and not simply cared for, and thereby allowed to resume its inherently formative path.

More recently Kovel has given a more concrete indication of what might be considered as historically embedded "virtual seeds" of ecosocialist economic practices. In

16 It should be noted that Princen's perspicacious discernment of the actualisation of different virtual possibilities within capitalism's "crystal of seeds" is not an isolated instance of an alternative economic approach, predicated on the possibility of opening up a different, sustainable future. Although there is no space for detailed discussion of other such instances, it is worthwhile taking a closer look at them, including those discussed by Castells et al (2012) and Hawken (2007). 
"Ecosocialism as a Human Phenomenon" (2013: 6) he intimates that historically older social structures, which are comparatively less estranged from nature, and from integration with natural ecosystems, are more capable of resisting capitalism's eco-destructive drive towards accumulation. He states that “...each capitalist society exists in relation to its own indigenous precursors. Notwithstanding, indigeneity serves as an important index of ecosocialist potential. Societies like Western Europe, where both the actual presence and the cultural trace of the indigenous past are the most suppressed, also have the weakest potential for ecosocialist transformation" (Kovel 2013: 6). He contrasts the Andean nations of northern South America, where such indigenous potential is the greatest (not without persisting problems of yielding to the eco-destructive pressure of capitalist extraction), with Europe, and to these may be added, for similar reasons, the societies of Africa.

On the other hand, however, transferring the notion of "seed-crystals" to neoliberal capitalism implies precisely, and most conspicuously, the unlimited economic growth that the capitalist system is ostensibly based on. This is evident from the fact that, since the first "Earth Day" was celebrated on 22 April 1970 (Kovel 2002: 3) - because of the realisation that human economic activity poses a grave threat to the planetary ecosystem - unrestrained, rampant economic growth has taken place globally (for evidence of this, see Kovel 2002: 3-5). Astonishingly, the capitalist elites supported this new eco-awareness through the so-called "Club of Rome", which, accordingly, published a manifesto tellingly titled The limits to growth. As Kovel reminds one, no heed has been paid to this exhortation to limit the growth that is inseparable from capital. However, it is far greater cause for concern that, today, "...even the idea of limiting growth has been banished from official discourse" (Kovel 2002: 5). It seems that one may infer from this that, implicitly, either capitalism is regarded as being capable of limitless growth in the limited, encompassing ecosphere (absurd as it may be), or the institutions and agencies that are in a position to impose the necessary limits on such unbridled economic growth are either in denial and/or cynically indifferent to its probable outcomes regarding the prospects of life on Earth, which are touched on where Kovel states (2002: 5):

If the world were a living organism, then any sensible observer would conclude that this 'growth' is a cancer that, if not somehow treated, means the destruction of human society, and even raises the question of the extinction of our species. A simple extrapolation tells us as much, once we learn that the growth is uncontrollable. The details are important and interesting, but less so than the chief conclusion - that irresistible growth, and the evident fact that this growth destabilizes and breaks down the natural ground necessary for human [and non-human; B.O.] existence, means, in the plainest terms, that we are doomed under the present social order, and that we had better change it as soon as possible if we are to survive.

Needless to stress, if the temporal-historical implications of capitalism as a "crystal of seeds" with "virtually" unlimited growth were to be realised, all living beings on the planet face an increasingly uncertain future. According to this historical 
scenario the temporal circuit between virtuality and actuality would, and must unfold historically as the continual actualisation of those "seeds" carrying the quintessence of capitalism - that is, the seeds of limitless growth and profit at all costs - although, as shown above, there are other, different virtual seeds, some of which are already being actualised. Humanity is confronted with the challenge of utilising the temporal circuitry available to it in the crystal of seeds by working towards the historical actualisation of these more deeply buried historical "seeds" containing the virtual possibility of different economic systems. These include the seeds of what Princen (2005) calls the "logic of sufficiency" as well as the "ecosocialism" envisaged by Kovel, which is only marginally related to capitalism through shared traits such as productive economic activities.

\section{NEOLIBERAL CAPITALISM AS SOCIAL INCARNATION OF THE "DECAYING CRYSTAL"}

The final "time-crystal" to be considered here as interpretive metaphor regarding the neoliberal regime is the "decaying crystal". Here, too, it is the current state of planetary ecological systems under the corrosive rule of neoliberalism that provides the most persuasive context for demonstrating the hermeneutic efficacy and fecundity of Deleuze's notion of "time-crystals", which he employs so well for understanding the films of Visconti, where he detects instances of "crystalline environments" temporally decaying from within (see note 10). In Sex, time and power (2004: 11-12), Leonard Shlain paints a vivid picture of what one may term the "decaying crystal" of human history where he remarks that:

Our ancestors would...bring about the greatest mass extinction of large animals since the dinosaurs abruptly disappeared 65-million years ago. Through their ever burgeoning technological prowess, humans would plant crops, tend herds, invent writing, build the Parthenon, discover gunpowder, transform the ceiling in the Sistine Chapel, compose the Eroica Symphony, and eventually evolve into a biological force capable of influencing the very climate of the Earth. Eve's descendants have steadily accumulated the power to destroy each other in an unholy Armageddon and, like sleepwalkers, are shuffling toward a planetary ecological disaster. How could a slight, five-foot-tall, two-legged animal create such sublimity and yet wreak so much havoc in so minuscule an interval of Earth's history?

This passage captures succinctly the nature of the strange, paradoxical species capable of such opposing extremes, namely Homo and Gyna sapiens. The words that are particularly germane to the question of the "decaying crystal" of capitalism is the one where Shlain observes that humans, "like sleepwalkers, are shuffling toward a planetary ecological disaster". Shlain's remark is even more relevant today, judging by climatologist James Lovelock's book, The vanishing face of Gaia: A final warning (2009; see also Olivier 2010). In a nutshell, Lovelock paints a bleak picture of the prospects facing the inhabitants of this once verdant planet - he insists 
that humanity may as well accept that the lush world of the $20^{\text {th }}$ century is forever something of the past. Scientific evidence points overwhelmingly towards the fact that we are witnessing the Earth inexorably moving towards what he calls a "hot state", where many of the things and conditions that we now take for granted will have changed beyond recognition, and to our and other living beings' detriment.

If his conclusion is challenged by defenders of the economic status quo, I should hasten to point out that the global scientific community overwhelmingly supports his diagnosis - even the comparatively conservative Intergovernmental Panel on Climate Change (IPCC), in its latest report (2014), appears to agree with him, while scholars such as John Bellamy Foster and his fellow authors (in a book tellingly titled The ecological rift-capitalism's war on the Earth;2010) do not hesitate to list all the areas where the capitalist "logic of excess" has demonstrably brought the planet to the point where several of the crucial ecological "tipping points" have already been crossed (Foster, Clark and York 2010; Olivier 2014). Naomi Klein, too, in her latest book, is uncompromising in her indictment of capitalism as the culprit driving environmental "decay", as the title indicates: This changes everything: Capitalism vs. the climate (2014).

Returning to Lovelock (whose work must be seen in the light of the by now indisputable anthropogenic causes of climate change brought forward by Foster and others, among other deleterious processes), his diagnosis of the state of the planet which bears on capitalism comprising a "crystal of decay", where the temporal circuit between the virtual and the actual seems to be shrinking in an accelerating historical process - is a multi-faceted one that takes into consideration many variables not often referred to in discussions of climate change. Lovelock makes a distinction between those scientists who work with theoretical models for climate prediction, and those who - within such a theoretical framework - are engaged in ongoing, painstaking observation and measurement of certain climate conditions. In the latter case the theory concerned is Lovelock's "Gaia theory", which considers the Earth as a single, if enormously complex and variegated, physiological, geophysical and biological system.

Lovelock and like-minded scientists do not rely on the projection of theorybased, anticipated conditions, are constantly engaged in observing and measuring existing conditions to be able to adjust their present "picture" of the Earth system, and are reluctant to predict any conditions which are inaccessibly distant from the present in observational terms. On the other hand, scientists who work with climate models in order to predict what the climate will be like in, say, four decades' time, extrapolate from present conditions in terms of a set of assumed conditions about the current geophysical state of the planet, the rate of change in greenhouse gas emissions, and so on. Although Lovelock recognises the work done by scientists who use the modelling approach, he explains why such an approach is inadequate when it comes to forecasts pertaining to decades into the future. For one thing, 
it assumes that the rate of heating of the planet will be an even, gradual process, and second, that humanity will be able to restrict it to only $2^{\circ} \mathrm{C}$ by 2050 , when the global population is expected to stabilise around eight billion. Moreover, it is almost entirely based on atmospheric physics, while a full understanding of the planet's climate, according to Lovelock, involves far more than this, including a thorough knowledge of the way that living creatures (animals, humans and plants, particularly in forests) influence the climate. In fact, one of the things that recommends Lovelock as scientist (he is also a geophysiologist) is his multi-disciplinary approach, where he constantly brings the latest findings of geophysics, marine biology, plant and animal physiology, biochemistry, as well as ongoing measurements of Earth conditions by scientists and satellites into an illuminating constellation.

The expectation that humanity can control climate modifications to keep them within bearable limits, when expressed by the ostensibly authoritative IPCC, feeds into international policies on climate change, despite being severely misleading. It is absurd for scientists like those on the IPCC to commit themselves to such a (politically correct and reassuring) forecast, decades into the future, because, as Lovelock points out, science is a "probabilistic" discipline, where hardly anything can be predicted with complete certainty when so many variables are at stake. The variables used in climate models are subject to change in a very short time, making a mockery of what was predicted, as it happened regarding faulty model predictions pertaining to the hole in the ozone layer. Everything considered, however, Lovelock believes it is likely that the heating of the Earth will continue at a comparatively accelerated rate. Regardless of disputes among scientists and other parties, like representatives of corporations, he points out several indisputable factors indicative of a steady rise in global temperature, including the progressive rise in sea level worldwide (predicted to be between 2 and $4 \mathrm{~cm}$ worldwide from 1970 until 2007, but eventually measured as being almost $5 \mathrm{~cm}$ instead). The height of the Earth's atmosphere is an equally reliable yardstick, because like water, the air expands as it gets hotter.

A brief summary of the disconcerting consequences of climate change that Lovelock foresees (as based on his scientific findings) will have to suffice here. Given the present greenhouse condition of the planet, the first stabilisation of global temperature that one can reasonably expect, is at $5^{\circ} \mathrm{C}$ above present temperature levels. Moreover, this "jump" to a "hothouse state" will probably (as in his experimental setup) be precipitated by a relatively small increase in heat or in carbon dioxide (or methane, nitrous oxide, and/or CFCs) quantities in the atmosphere. Based on his experiment, before the rapid escalation to global desert status, there will probably be a brief period of cooling down, manifested in a cool summer, or a series of them. As might be expected, a rapid rise in world temperature will be nothing short of catastrophic - if it happens; Lovelock stresses that unpredictable events (such as significant numbers of atmosphere-cooling, vapour-emitting volcanic eruptions) could prevent it from happening. There are many factors worldwide at present 
(listed by him) that indicate a movement in that direction, however, such as the increasing acidification of the world's oceans (which has already turned vast areas of ocean into "dead zones", with no sign of life), the growing desertification of many land areas, and so on. What one witnesses here, is nothing less than a process of ecological "decomposition" of existing planetary conditions, being played out in the temporal circuit between virtual and actual aspects of the capitalist "crystal of decay". Lovelock compares the Earth and its human inhabitants to a terminally ill patient: (Lovelock 2009: 46-47):

Scientists, who recognize the truth about the Earth's condition, advise their governments of its deadly seriousness in the manner of a physician. We are now seeing the responses. First was denial at all levels, then the desperate search for a cure. Just as we individuals try alternative medicine, our governments have many offers from alternative business and their lobbies to "save the planet", and from some green hospice there may come the anodyne of hope.

If anyone doubts the validity of this grim prospect, consider the forces now taking the earth to the hothouse, such as the increasing abundance of greenhouse gases from industry and agriculture, including gases from natural ecosystems damaged by global heating in the Arctic and the tropics. The vast ocean ecosystems that used to pump down carbon dioxide can no longer do so because the ocean turns to desert as it warms and grows more acidic. Add to this the extra absorption of the sun's radiant heat by the planetary surface, as white-reflecting snow melts and is replaced by dark ground or ocean. Each separate increase adds heat, and together they amplify the anthropogenic warming. Small wonder that, contrary to popular climate wisdom, Lovelock concludes (2009: 50):

There is no tipping point; we are sliding down a bumpy slope that grows ever steeper to the future hot world. Even in the survival havens [including the UK and New Zealand; B.O.] where climate change is gentle enough to allow the continued growth of food there will be disasters and difficulties. Thus in the more fertile parts of Europe unaffected by heat and drought, including the Netherlands, the UK and Ireland, rising sea level and storms may lead to catastrophic inundations. Much of London is likely to be flooded, and the underground transport system disabled. The Netherlands may be uninhabitable...

The worst source of suffering and large-scale dying of living beings, Lovelock believes, will be drought. All living creatures depend on water for survival, and as the water resources of the world dwindle more and more, it is not impossible that wars may ensue over access to it (as has already happened in Darfur). So what is to be done, in light of what capitalism's "crystal of decay" enables one to prognosticate along the circuit between virtual and actual elements of a temporal-historical trajectory? Lovelock's advice to governments worldwide is to jettison the belief that a process that has been gathering momentum for more than a century can be stopped or reversed by turning to alternative energy sources (the "green economy"); 
on scientific grounds he believes that this is unlikely, and that the best we can do is to secure our water and food resources as much as possible for surviving the hot climate of the future.

\section{CONCLUSION}

Despite being transferred from Deleuze's philosophy of the time-image in cinema, the metaphor of "time-crystals" has proved to have significant explanatory value for the interpretation of human subjectivity and social history. This is not surprising when one reflects on the fundamental temporal constitution of the human subject, as encountered in the work of Kant, ${ }^{17}$ which comprises a revolutionary departure from the millennial rule of the Aristotelian reduction of time to movement, as argued earlier. It was also pointed out that the passage from Aristotle to Kant is replicated in historically condensed fashion, in the transition from what Deleuze calls the cinema of the movement-image to that of the time-image. It has been my contention in this paper that Deleuze's elaboration on the latter - particularly in terms of what he calls "time-crystals" - comprises a fecund conceptual terrain for comprehending the temporal structure of subjectivity as well as of social history. The latter has been demonstrated by means of an investigation of neoliberal capitalism as refracted through the four types of "time-crystal" distinguished by Deleuze, to wit, the "perfect crystal", the "flawed crystal", the "crystal of seeds" and the "decaying crystal". As shown above, it is particularly in the case of the "flawed" and the "decaying" crystals that the quasi-transcendental character of temporality itself is revealed, insofar as it is shown that time is not merely the prerequisite for actualising virtual possibilities in a "positive" sense (as with the "crystal of seeds" and the "perfect crystal", although the latter is arguably never actualised in social reality), but also for the subversion and dismantling of such "positivity" or completeness. This exploration of the interpretive potential of Deleuze's notion of "time-crystals" is not exhaustive, of course, and could be taken further by filling in and expanding on the interstitial hermeneutic spaces lending themselves to further investigation and finer nuancing.*

\section{REFERENCES}

Amenábar, A. (Dir.). 2004. The sea inside. New Line Cinema (USA).

Ardolino, E. (Dir.). 1987. Dirty dancing. Great American Films Limited Partnership.

17 One could follow the historical trail of this revolution in the work of figures such as Nietzsche, Bergson, Husserl, Heidegger and Derrida, but it falls outside the scope of this paper.

* The financial assistance of the National Research Foundation of South Africa, which has contributed to making this research possible, is hereby gratefully acknowledged. 
Bennington, G. 1993. Derridabase. (Concurrently with Derrida's parallel text). In Jacques Derrida, J. Derrida and G. Bennington. Trans. G. Bennington. Chicago: The University of Chicago Press.

Bergson, H. 1910. Time and free will. An essay on the immediate data of consciousness. Trans. F.L. Pogson. London: George Allen and Unwin.

Bergson, H. 1911. Matter and memory. Trans. N.M. Paul and W.S. Palmer. London: George Allen and Unwin. E-book, http://www.reasoned.org/dir/lit/matter_and_memory.pdf

Bergson, H. 1922. Creative evolution. Trans. A. Mitchell. London: Macmillan.

Boundas, C.V. 2010. Virtual/Virtuality. In The Deleuze dictionary. Revised Edition. Edited by A. Parr. Edinburgh: Edinburgh University Press, pp. 300-302.

Buchanan, I. 2008. Introduction: Five theses of actually existing schizoanalysis of film. In Deleuze and the schizoanalysis of cinema. Edited by I. Buchanan and P. MacCormack. London: Continuum, location 42-242. (Kindle edition.)

Caputo, J.D. (Ed.). 1997. Deconstruction in a nutshell. A conversation with Jacques Derrida. New York: Fordham University Press.

Castells, M., Caraca, J. and Cardoso, G. (Eds.). 2012. Aftermath - The cultures of the economic crisis. Oxford: Oxford University Press.

Chaplin, C. (Dir.). 1936. Modern times. Criterion DVD Collection. Released 2010.

Deleuze, G. 1986. Cinema 1: The movement-image. Trans. H. Tomlinson and B. Habberjam. Minneapolis: University of Minnesota Press.

Deleuze, G. 1999. Kant's critical philosophy. The doctrine of the faculties. Trans. H. Tomlinson and B. Habberjam. Minneapolis: The University of Minnesota Press.

Deleuze, G. 2004. Difference and repetition. Trans. P. Patton. London: Continuum.

Deleuze, G. 2005. Cinema 2: The time-image. Trans. H. Tomlinson and R. Galeta. New York: Continuum.

Deleuze and Guattari. 1983. Anti-Oedipus. Capitalism and schizophrenia (Vol. 1). Trans. R. Hurley, M. Seem \& H.R. Lane. Minneapolis: University of Minnesota Press.

Deleuze and Guattari. 1987. A thousand plateaus. Capitalism and schizophrenia (Vol. 2). Trans. B. Massumi. Minneapolis: University of Minnesota Press.

Easton Ellis, B. 1991. American psycho. New York: Vintage Books.

Foster, J.B., Clark, B. and York, R. 2010. The ecological rift-capitalism's war on the earth. New York: Monthly Review Press.

Freud, S. 2011. New introductory lectures on psycho-analysis. In Freud-Complete works. Ivan Smith (pub.), pp. 4617-4778.

Hardt, M. and Negri, A. 2006. Multitude. War and democracy in the Age of Empire. London: Penguin Books.

Harvey, D. 1990. The condition of postmodernity. Oxford: Basil Blackwell.

Hawken, P. 2007. Blessed unrest - How the largest movement in the world came into being and why no one saw it coming. New York: Penguin.

Intergovernmental Panel on Climate Change (IPCC). 2014. Climate change: Impacts, adaptation, and vulnerability. Fifth Assessment Report. New York: Cambridge University Press. 
Kant, I. 1929. Immanuel Kant's critique of pure reason. Trans. N.M. Smith. London: Macmillan and Company.

Klein, N. 2007. The shock doctrine: The rise of disaster capitalism. London: Allen Lane Penguin.

Klein, N. 2014. This changes everything: Capitalism vs. the climate. Toronto: Alfred A Knopf.

Kovel, J. 2002. The enemy of nature. The end of capitalism or the end of the world? London \& New York: Zed Books.

Kovel, J. 2013. Ecosocialism as a human phenomenon. Ecosocialist Horizons, August 3: http:// ecosocialisthorizons.com/2013/08/ecosocialism-as-a-human-phenomenon/ (accessed 31 January 2016).

Lazzarato, M. (No date available.) Immaterial labor. Generation Online. http://www.generationonline.org/c/fcimmateriallabour3.htm (accessed 17 April 2016).

Lovelock, J. 2009. The vanishing face of Gaia: A final warning. London: Penguin Books.

Lyotard, J.F. 1991. "Rewriting modernity". In The inhuman. Reflections on time. Trans. G. Bennington and R. Bowlby. Cambridge: Polity, pp. 24-35.

Marx, K. 1972. The Grundrisse. Trans. D. McLellan. New York: Harper Torchbooks.

Olivier, B. 2010. Lovelock's final warning. Mail \& Guardian Thoughtleader site: http://www. thoughtleader.co.za/bertolivier/2010/06/20/lovelock\%E2\%80\%99s- $\%$ E2\%80\%98finalwarning\%E2\%80\%99/ (accessed 16 April 2015).

Olivier, B. 2012. Different 'percepts' of the human body in cinema. South African Journal of Art History, 27(2): 79-97.

Olivier, B. 2014. The 'Network Society', Social transformation, and the 'Ecological Rift'. Alternation - Interdisciplinary Journal for the Study of the Arts and Humanities in Southern Africa, 21(2): 122-155.

Plato. 1991. The Republic of Plato. Trans. A. Bloom. Basic Books.

Princen, T. 2005. The logic of sufficiency. Cambridge, Mass.: MIT Press.

Rancière, J. 2013. The politics of aesthetics. The distribution of the sensible. Trans. G. Rockhill. London: Bloomsbury. (Kindle edition.)

Resnais, A. (Dir.). 1961. Last year at Marienbad. France: Cocinor.

Roeg, N. (Dir.). 1980. Bad timing. U.K.: Rank Film Productions.

Ross, H. (Dir.). 1984. Footloose. USA: Paramount Pictures.

Shakespeare, W. 1994. The tragedy of Hamlet, Prince of Denmark. In The complete works of William Shakespeare, Project Gutenberg e-text, pp. 420-499.

Shlain, L. 2004. Sex, time and power. New York; Penguin Books.

Tanke, J.J. 2011. Jacques Rancière: An introduction. New York: Continuum.

Van Haute, P. 2013. Het project van een pathoanalyse van het bestaan in Freuds Drie verhandelingen over de theorie van de seksualiteit (1905). In Freud als Filosoof - Over Seksualiteit, Psychopathologie en Cultuur, edited by P. van Haute and J. de Vleminck. Kalmthout: Pelckmans Uitgeverij, pp. 31-47.

Winkler, I. (Dir.). 1995. The Net. USA: Columbia Pictures.

Yeats, W.B. Sailing to Byzantium. Online literature: http://www.online-literature.com/yeats/781/ (accessed 22 May 2015). 